Botany" (1864), or in Bentham's famous "Handbook" (1924), or in Bonnier's "British Flora" (1925) or in any similar work to which $I$ have access. Brimble, in his "Flowers in Britain" (1944), does not query Smith's statement; but, though he refers to the flower heads being "borne at the ends of thick, erect stalks with hairy bracts", he does not state that the flower buds droop. Furthermore, an illustration shows an erect flower bud.

\section{THE BROAD TAPEWORMS OF MAN, CORMORANTS AND GULLS}

T. B. DUGUID and E. M. Sheppard (J. Path and Bact., 56,73 ; 1944. See also Nature, 154, 185 ; 1944) described their discovery of plerocercoids of a Diphyllobothriid tapeworm in freshwater trout and sticklebacks in a South Wales reservoir and their work on its life-history. M. D. Hickey and J. R. Harris (Brit. Med. J., 310, Sept. 2, 1944) also found Diphyllobothriid plerocercoids in trout in the Dublin area, and a Diphyllobothriid adult tapeworm in seagulls and cormorants there (see also M. D. Hickey, Brit. Med. J., 482, Oct. 7, 1944, and K. Unsworth, ibid., 385, Sept. 16, 1944). K. Unsworth (Ann. Trop. Med. and Parasit., 38, 213 ; 1944) has now published the results of his work on the life-history of the South Wales species.

Starting with a rat infested by Duguid and Sheppard, Unsworth was able to confirm the results obtained by them. He successfully infested the copepods Cyclops strenuus and Diaptomus gracilis, which Duguid and Sheppard also used, but found. that the former was the best first intermediate host. The nauplius larva of Cyclops readily ate the coracidia, which were fully developed by the time that the later copepod stages were reached. After 16-20 days of development in Cyclops, which Unsworth describes, the Cyclops were fed to sticklebacks, in which plerocercoids were obtained, chiefly in cysts on the serous surface of the stomach, under the peritoneum and under the liver capsule. When these sticklebacks were fed to one pike, which is known to be a second intermediate host of Diphyllobothrium latum of man, one plerocercoid was obtained from the pike. When plerocercoids from both the infested sticklebacks and the pike were fed to puppies aged $2-3 \frac{1}{2}$ months, the adult tapeworm developed in the puppies, which passed eggs in their fæces. Coracidia from these eggs infested Cyclops. Unsworth makes the interesting and epidemiologically important suggestion that the overwhelming infestation of the trout in so large an expanse of water in South Wales (100 per cent) was due to the fact that the trout ate sticklebacks which had already infested themselves by eating infested copepods. He supports this suggestion by the observation that the commoner fish hosts which harbour plerocercoids of Diphyllobothriid species (for example, perch, pike, wall-eyed pike, trout and burbot) are all fish-eating species, while the less common fish hosts of these plerocercoids (for example, grayling and pollan) eat fish only at times. Unsworth was unable to identify the species of Diphyllobothrium with which he was dealing, because he obtained only the scolex and immature anterior segments of the adult from the puppies which he experimentally infested; but, from these, he concluded that the South Wales species studied by him was too small to be D. latum of man. $\mathrm{He}$ was also able to infest puppies with plerocercoids sent to him by Hickey from the Dublin area, so that this Dublin species can apparently develop to maturity both in a mammal and in birds (gulls, herring gulls and cormorants). Unsworth concluded that the Irish species is not Diphyllobothrium latum of man. The immature stages are not, however, enough for the identification of species of Diphyllobothrium.

All these workers sent specimens of the adult tapeworms obtained by them to H. A. Baylis of the British Museum, who concludes (Brit. Med. J., 868, Dec. 30,1944 ) that all the tapeworms obtained from the gulls represented one species, and all those from the cormorants another. Comparison of the worms obtained from the experimental mammalian hosts by all the workers led Baylis to conclude that all the workers were dealing in their experiments with a single species, which is probably the old but littleknown species $D$. dendriticum (Nitzsch, 1824). In experimental mammalian hosts this species showed slight differences from species found in gulls, probably because the mammal is an abnormal host.

The question raised in the Lancet (475, April 8, 1944) that the species found in "South Wales might possibly be $D$. latum of man, which does occur in the west of Ireland (see below) and might possibly have been brought to Britain by Polish and Norwegian refugees, as it has been established endemically in North America by immigrants, would seem to have been negatived by Baylis's decision. The whole question, however, requires further investigation, for T. E. Gibson (Brit. Med. J., 200, Feb. 10, 1945) records yet another infestation of trout in a Northamptonshire reservoir with plerocercoids morphologically similar to those described by Duguid and Sheppard. These failed to infest a guinea pig, but they did infest three rats, which finally threw off the infestation spontaneously, as Unsworth's puppies did. Gibson also found plerocercoids "of a smaller type" in 40 per cent of "smaller fish" in the same reservoir, but attempts to infest rats with these have so far failed (see also T. Hare, Brit. Med. J., 347, March 10, 1945). In addition to this, Dr. Peterson of Yell informed Duguid and Sheppard that a species of Diphyllobothrium is also endemic among freshwater trout in some of the Shetland Islands.

With regard to the occurrence of Diphyllobothrium latum in man in west Ireland, N. O'Connor (Brit. Med. $J ., 737$, Dec. 2, 1944), discussing multiple infestation of man with two types of tapeworm, states that the existence in Ireland of $D$. latum of man was first recorded by O'Farrell (Lancet, i, 466, 1916 ; i, 570, 1918 ; and Irish J. Med. Sci., vi, 95; 1929). Another case was reported by O'Kelly (Irish J. Med. Sci., vi, 188 ; 1935). The first case of multiple infestation was recorded by O'Farrell (Irish J. Med. Sci., vi, $542 ; 1930)$. All these cases came from the Shannon area. O'Connor (loc. cit.) himself records the infestation of a husband and wife with D. latum in the River Erne area, near lakes not connected with the River Shannon, the wife's infestation being multiple and combined with infestation with Taenia saginata. Both ate perch, pike and eels, but no trout; the wife often ate undercooked meat and raw pork. The husband had never been abroad; the wife was born of Irish parents in Glasgow, which town she had visited only twice within the last twenty-three years. G. W. S. Andrews and A. C. Ogilvie (Brit. Med. J., 772, June 3, 1944) record a case of multiple infestation with Taenia saginata. G. LAPAGE. 